\title{
Practices employed by veterinary practitioners for controlling canine gastrointestinal helminths and ectoparasites
}

\author{
Práticas realizadas por veterinários para controle de helmintos gastrintestinais \\ e ectoparasitos de cães
}

\begin{abstract}
Tássia Lopes do Vale ${ }^{1}$ (D); Isabella Chaves Sousa² (D); Caio Pavão Tavares (D); Naylene Carvalho Silva ${ }^{1}$ (D); Hermes Ribeiro Luz ${ }^{2}$ (D); Matheus Nobate Gomes ${ }^{3}$ (D); Neil Sargison ${ }^{4}$ (D); Livio Martins Costa-Junior ${ }^{1 *}$ (d)

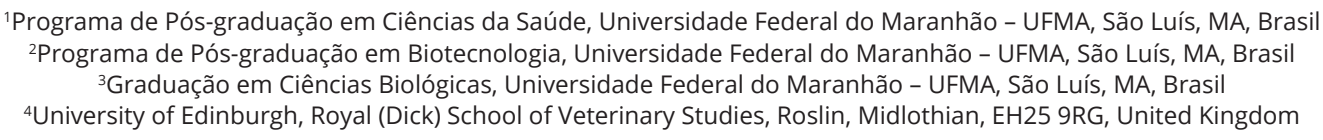

How to cite: do Vale TL, Sousa IC, Tavares CP, Silva NC, Luz HR, Gomes MN, et al. Practices employed by veterinary practitioners for controlling canine gastrointestinal helminths and ectoparasites. Braz J Vet Parasito/ 2021; 30(4): e007021. https://doi.org/10.1590/ S1984-29612021079

\begin{abstract}
The present study attempted to evaluate the practical experience and methods employed by Brazilian veterinary practitioners for control of parasites. Twenty-one questions were asked of 403 veterinary practitioners based in different climatic zones with reference to parasite epidemiology from the country. Administration of a combination of drugs at three-month intervals was the most common regime recommended for prophylaxis against gastrointestinal helminths, with a single treatment repeated after 15 days. Routine prophylaxis against dog ectoparasites was recommended by $82.4 \%$ veterinary practitioners, and $46.6 \%$ changed the drug compound used. Monthly prophylaxic treatments for ectoparasites, using systemic, topical and/or collar-impregnated drugs, was recommended by $21.5 \%$ veterinary practitioners. Side-effects of ectoparasiticide-impregnated collars were suspected by $58 \%$ of the veterinary practitioners. Isoxazolines were the most frequently used chemical group to treat ectoparasites in dogs. Poor efficacy of fipronil in controlling ticks was suspected by $79.5 \%$ of the veterinary practitioners. The isoxazolines and combination of anthelmintic compounds are the most common drugs to prevent or treat ectoparasites and gastrointestinal nematodes, respectively. The suspect of the inefficacy of antiparasitic drugs is shared among the veterinary practitioners from part of Brazil. Guidelines are needed, specifically for the control of gastrointestinal helminths and ectoparasites in Brazilian dogs.
\end{abstract}

Keywords: Gastrointestinal nematodes, ectoparasites, dogs, antiparasitic drugs, control strategies.

\begin{abstract}
Resumo
O presente estudo avaliou os métodos de controle empregados por médicos veterinários clínicos para o controle de parasitos de cães no Brasil. Vinte e uma perguntas foram feitas a 403 veterinários de diferentes regiões do país. O uso de associações de compostos ativos em intervalos de três meses foi o mais recomendado para profilaxia de helmintos gastrointestinais, repetido após 15 dias. A profilaxia de rotina contra ectoparasitos foi recomendada por $82,4 \%$ dos veterinários, e $46,6 \%$ mudam rotineiramente o composto indicado. Tratamentos profiláticos mensais para ectoparasitos, com produtos sistêmicos, tópicos e / ou impregnados com colar, foram recomendados por $21,5 \%$ dos veterinários. Os efeitos colaterais das coleiras impregnadas com ectoparasiticidas foram relatados por $58 \%$ dos médicos veterinários. As isoxazolinas foram o grupo químico mais utilizado para tratar ectoparasitos em cães. A baixa eficácia do fipronil no controle de carrapatos foi suspeitada por $79,5 \%$ dos médicos veterinários. As isoxazolinas e a associação de compostos anti-helmínticos são os medicamentos mais comuns para prevenir ou tratar ectoparasitos e nematoides gastrointestinais, respectivamente. A suspeita
\end{abstract}


da ineficácia dos antiparasitários é compartilhada entre os médicos veterinários de algumas regiões do Brasil. Orientações são necessárias, especificamente para o controle de helmintos e ectoparasitos gastrointestinais em cães no Brasil.

Palavras-chave: Nematódeos gastrointestinais, ectoparasitos, cães, antiparasitários, estratégias de controle.

\section{Introduction}

Parasites are important global causes of infectious disease in dogs, in particular in warm and humid tropical environments that provide optimal conditions for survival and development of free-living stages of a variety of parasitic arthropods, protozoa and helminths, many associated with dogs (Dantas-Torres et al., 2020). Brazil is the largest tropical country in the world, occupying a highly diverse land area; and has approximately 55.1 million dogs (ABINPET, 2019; IBGE, 2019). These conditions are ideal for the completion of parasite life cycles and facilitate disease transmission.

Several common canine gastrointestinal helminth (in particular, Toxocara canis and Ancylostoma spp.) and arthropods (in particular, ticks, phlebotomine sand flies and mosquitoes) parasites are responsible for zoonotic diseases in Brazil (Dantas-Torres \& Otranto, 2014). Effective and sustainable gastrointestinal helminth and arthropod parasite control is, therefore, a fundamental priority to ensure good states of welfare in dogs and reduce the potential for zoonotic transmission (Chomel \& Sun, 2011). Recognised best practice should involve both management, such as addressing the sanitary conditions of the environment to interrupt parasite life cycles, and use of antiparasitic drugs strategically targeted to account for factors involved in the parasites' life histories (Alho et al., 2018). However, there is a global tendency among dog owners and veterinary practitioners to rely on the simpler option of regular and non-targeted, one-fits-all antiparasitic drug treatments.

Guidelines have been elaborated for the treatment and control of companion animal parasites in north America, Europe and Tropical regions under the auspices of the Companion Animal Parasite Council (CAPC) founded in 2002 (CAPC, 2019), the European Scientific Council Companion Animal Parasites (ESCCAP) founded in 2005 (ESCCAP, 2019), and the Tropical Council for Companion Animal Parasites (TroCCAP) founded in 2015 (Traub et al., 2015) (TroCCAP, 2019). These guidelines were updated in 2020, with the notable addition of highlighting the need to disseminate information to veterinary practitioners in tropical regions (Dantas-Torres et al., 2020).

Faced with the emergence of antiparasitic drug resistance (Furtado et al., 2014; Becker et al., 2019), Brazilian veterinary practitioners have an important role in ensuring the sustainable control of the large diversity of gastrointestinal helminths and arthropods that affect dogs. The present study, therefore, aimed to evaluate the practical experience and methods employed by veterinary practitioners for parasite control in dogs in Brazil, using a structured questionnaire format. This included questions that explored perceptions of drug efficacy and specific side-effects. Critical knowledge gaps relating to the practicalities of diagnosis, treatment, and control of parasitic diseases of dogs are identified with reference to better informing Brazilian veterinary practitioners.

\section{Materials and Methods}

\section{Study population}

There are 124,253 registered veterinary practitioners in Brazil, albeit the true number of these working with companion animals is unknown (CFMV, 2019). In this context was used the formula to infinite population described by Miot (2011) was to calculate a requirement to question 384 veterinary practitioners in order to generate representative responses with a 95\% confidence level (the true percentage of the population who would pick an answer, $\mathrm{Z} \alpha / 2=1.96)$ and a margin of error (referred to here as a confidence interval) of $5 \%(E=0.05)$. The $\delta$ was considered as 0.5 .

$$
n=[(Z \alpha / 2 \times \delta) \div \mathrm{E}]^{2}
$$

A questionnaire survey was developed to explore theoretical knowledge and understanding of canine parasitology as it pertains to situations that are routinely encountered in veterinary practices. The sample collect was by convenience in two different moments. Firstly, the questionnaire was delivered online to veterinary practitioners working with companion animals, and publicised through social media and personal mailing lists of the Brazilian 
authors. In addition, veterinary practitioners who participated in the Brazilian Conference of Small Animals Clinic (BCSAC) in 2018 were invited to fill out the questionnaire in printed form. Because of the type of sampling and mainly because of the BCSAC audience, the sample studied may not represent the entire population of Brazilian veterinary practitioners. This methodological bias must be considered in this study. The respondents could freely not answer any questions, or give up on completion at any stage. Duplicate responses were excluded, along with those from veterinary practitioners without a professional registration number, or from another country. All responders freely consented to their participation in the survey and personal data were not exposed. All personal data were handled only by two members of the research team, further ensuring total data protection and anonymity. All data were handled according to Brazilian data protection law current at the time of the survey.

\section{Questionnaire structure}

The questionnaire was designed first to obtain data pertaining to inclusivity, and to gauge the respondents' attitudes towards parasite control. This was followed by 13 closed, six open and two mixed questions that were subdivided into two sections according canine gastrointestinal helminth or arthropod parasites (Supplementary material). Parasitic protozoa and Dirofilaria immitis were not the focus of the present study to avoid potential confusion with the diagnosis and management of gastrointestinal helminth and tick-borne parasites. Specific risk factors such as host age, hygiene and environmental conditions were also not analysed in the present study.

Questions in the gastrointestinal helminth section explored knowledge and attitudes towards coproparasitological examination, principles of antiparasitic drug use, anthelmintic resistance mitigation, and perceptions of drug efficacy. Questions in the arthropod section explored knowledge of and attitudes towards common ectoparasite infestations, treatment and prophylaxis regimes using systemic, topical and/or impregnated collar formulations, drug side-effects, drug resistance or tolerance mitigation strategies, and suspicion of drug inefficacy. More than one response was possible for questions about common ectoparasites and antiparasitic drug use, and suspicion of inefficacy. The questionnaire was piloted and refined with seven veterinarians, and the final version is shown in the supplementary material.

\section{Data analysis}

Five hundred and thirty-two responses were received. One duplicate entry, 123 responses from unregistered veterinary practitioners (veterinary students, or failure to provide a professional registration number), and five responses from non-Brazilian veterinarians were removed, leaving a total of 403 responses from veterinary practitioners based across Brazil ( $5 \%$ more than the calculated target). A comparison of the number of responders and the distribution of the Brazilian population (IBGE, 2012) of each geographic region was performed using Chi-square to demonstrate that the sample was representative of the country. The responses were coded and transformed into spreadsheets using Epi-Info ${ }^{\circledR}$ software 7.2.2.6 (Centres for Disease Control and Prevention; USA). Drugs that were described by label name were identified using the SINDAN website (SINDAN, 2019) and entered according to the active compounds. The final data were summarised into percentages, and Chi-square and Fisher's exact tests were used to perform pairwise comparisons between categories of the same independent variable proportions. A p value $<0.05$ was considered as statistically significant. Analyses were performed using GraphPad Prism 7.0 (Graphpad Software, Inc., San Diego, CA, USA).

Distribution maps of responders and of suspected fipronil resistance in each state and Brazilian biomes were created using the program QGis 3.14. The shapes of Brazilian biomes and states were obtained from the Brazilian Institute of Geography and Statistics (IBGE) database (https://portaldemapas.ibge.gov.br/portal.php\#homepage) (IBGE, 2019).

\section{Results}

The 403 respondents were veterinary practitioners working in 149 municipalities (from the total of 5,568 municipalities of Brazil) from 24 of the 27 Brazilian states, distributed proportionally according to Brazilian population across each political region (Figure $1 \mathrm{~A}$ ). Of the six official biomes present in Brazil, no responses were received from Pantanal (Figure 1A), which represents only 1.8\% of the total Brazilian territory area (IBGE, 2019). Analysis of the data by biome was not the purpose of the present study and was not performed; nevertheless the description of responses from different Brazilian biomes was important to demonstrate that the data were 
A
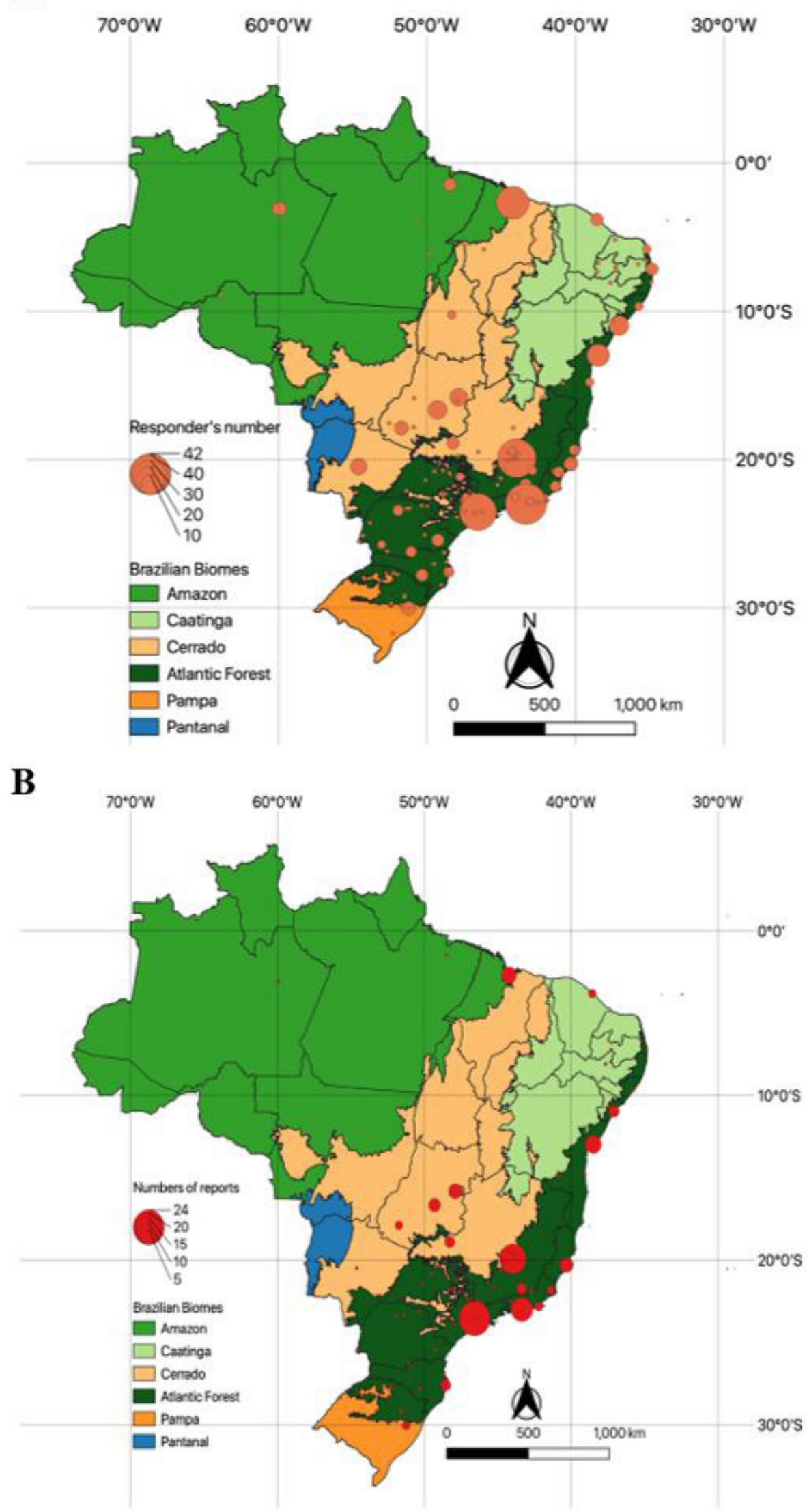

Figure 1. Distribution of the number of responders $(A)$ and reports of inefficacy suspicious of fipronil against ectoparasites (B) in different states and biomes of Brazil. 
representative. Two hundred and eighty-eight (71.4\%) of these respondents stated (from a veterinary practitioner perspective) that dog owners consider parasite control to be important.

\section{Gastrointestinal helminth control practices}

The drugs used by Brazilian veterinary practitioners for treatment or prophylaxis of canine gastrointestinal helminths are shown in Table 1. Each drug was considered as one response and multiple responses were accepted giving rise to 495 responses describing recommended drugs. The multiple responses were not considered as concomitant treatments. Drug combinations were deduced from commercial brands. $32.3 \%$ of the responses recommended treatment with a single drug active $(n=160$ from benzimidazoles, pyrazinoisoquinoline, pyrimidine and macrocyclic lactone chemical groups) and $62.2 \%$ recommended the use of drugs with combinations of compounds $(n=308)$. A combination of praziquantel plus pyrantel plus febantel was most commonly used with $25.3 \%$ recommendation by Brazilian veterinary practitioners. Treatments with a single active, such as praziquantel (7.9\%), ivermectin (5.7\%) and albendazole (5.1\%) were recommended by some veterinary practitioners.

Eighty-three respondents (20.6\%) perceived anthelmintic inefficacy, and a further five respondents who reported suspected inefficacy of two drugs. Inefficacy was suspected for benzimidazole drugs (28.4\%), combinations of drugs (23.9\%) and, macrocyclic lactones (12.5\%) (Table 1). Despite the large range of anthelmintic compounds available in Brazil, only $57.0 \%$ of the respondents routinely changed the drug that they recommended.

Table 1. The percentages and number of responses (in bracket) showing the chemical groups and drug compounds recommended by Brazilian veterinarians for treatment and prophylaxis of canine gastrointestinal helminths and suspicion of inefficacy.

\begin{tabular}{|c|c|c|}
\hline Chemical group / compound & Recommended $^{1}$ & Suspect inefficacy ${ }^{2}$ \\
\hline Benzimidazoles & $14.3(71)^{\mathrm{B}}$ & $28.4(25)^{A}$ \\
\hline Albendazole & $5.1(25)^{c, d}$ & $8.0(7)^{\mathrm{a}}$ \\
\hline Fenbendazole & $2.2(11)^{\mathrm{e}}$ & $8.0(7)^{a}$ \\
\hline Febantel & $4.2(21)^{\mathrm{d}, \mathrm{e}}$ & $2.3(2)^{b}$ \\
\hline Mebendazole & $2.8(14)^{\mathrm{e}}$ & $10.2(9)^{a, b}$ \\
\hline Pyrazinoisoquinoline & $7.9(39)^{c}$ & $9.1(8)^{c}$ \\
\hline Praziquantel & $7.9(39)^{c}$ & $9.1(8)^{a, b}$ \\
\hline Pyrimidine & $2.2(11)^{\mathrm{D}}$ & $10.2(9)^{c}$ \\
\hline Pyrantel & $2.2(11)^{\mathrm{e}}$ & $10.2(9)^{a, b}$ \\
\hline Macrocyclic lactone & $7.9(39)^{c}$ & $12.5(11)^{\mathrm{B}, \mathrm{C}}$ \\
\hline Ivermectin & $5.7(28)^{c, d}$ & $10.2(9)^{a, b}$ \\
\hline Milbemycin oxime & $2.2(11)^{\mathrm{e}}$ & $2.3(2)^{b}$ \\
\hline Combinations & $62.2(308)^{A}$ & $23.9(21)^{A, B}$ \\
\hline Praziquantel+Febantel & $4.0(20)^{\mathrm{d}, \mathrm{e}}$ & - \\
\hline Praziquantel+Febendazole & $2.2(11)^{\mathrm{e}}$ & - \\
\hline Praziquantel+Pyrantel & $7.9(39)^{c}$ & $8.0(7)^{a, b}$ \\
\hline Praziquantel+Pyrantel+Febantel & $25.3(125)^{\mathrm{a}}$ & $9.1(8)^{a, b}$ \\
\hline Praziquantel+Pyrantel+Fenbendazole & $15.6(77)^{b}$ & $3.4(3)^{\mathrm{b}}$ \\
\hline Praziquantel+Pyrantel+Febantel+Ivermectin & $7.3(36)^{c}$ & $3.4(3)^{\mathrm{b}}$ \\
\hline Others & $5.5(27)^{c, d, c}$ & $15.9(14)^{a, B, c}$ \\
\hline
\end{tabular}

${ }^{1}$ Recommendations based on a total of 495 responses (multiple responses were allowed); ${ }^{2}$ Suspicion of inefficacy based on a total of 88 responses (multiple responses were allowed). In bold the total number of responses by chemical group or combination. The different letters signify statistical differences with $p<0.05$, being lower letters among the compounds and capital letters among the chemical group or combination. 
The regimes used by interviewed veterinary practitioners for the prophylaxis and treatment of canine gastrointestinal helminths are shown in Table 2. More respondents (46.1\%) recommended administration of prophylactic treatments at 3-month intervals. More respondents (60.7\%) recommended repeating drug administration after 15 days for the treatment of gastrointestinal nematode infections. Less the half (43.5\%) of veterinary practitioners requested laboratory examination to confirm parasite species infection before the treatment (Table 2). Those veterinary practitioners who requested laboratory confirmation, did so once (15.9\%), or twice a year (21.1\%).

Table 2. The percentages and number ( $n$ ) of responses (in bracket) of Brazilian veterinarian regimes of recommendations to control canine gastrointestinal helminths.

\begin{tabular}{lc}
\hline \multicolumn{1}{c}{ Regimes } & \% (n) \\
\hline Prophylaxis of gastrointestinal helminth & $18.8(76)^{\mathrm{b}}$ \\
Every month & $46.1(186)^{\mathrm{a}}$ \\
Every 3-months & $21.8(88)^{\mathrm{b}}$ \\
Every 6-months & $13.1(53)^{\mathrm{c}}$ \\
Other (irregular intervals) & $60.7(245)^{\mathrm{a}}$ \\
Treatment of gastrointestinal helminth & $18.8(76)^{\mathrm{b}}$ \\
Treatment and repeat after 15 days & $8.9(36)^{\mathrm{c}}$ \\
Treatment for three consecutive days & $10.9(44)^{\mathrm{c}}$ \\
Treatment for three consecutive days and repeat after 15 days & $0.5(2)^{\mathrm{d}}$ \\
Other (irregular intervals) & \\
Not answer & $52.6(212)^{\mathrm{a}}$ \\
Request laboratory examination & $6.0(24)^{\mathrm{c}}$ \\
No & $21.1(85)^{\mathrm{b}}$ \\
Every 3-months & $15.9(64)^{\mathrm{b}}$ \\
Every 6-months & $0.5(2)^{\mathrm{d}}$ \\
Once a year & $4.0(16)^{\mathrm{c}}$ \\
Other (irregular intervals) & \\
Not answer & \\
\hline
\end{tabular}

The different letters signify statistical differences with $p<0.05$ among different action for the same regime.

\section{Control practices against ectoparasites}

The most frequently reported canine ectoparasites were ticks followed by fleas, mites and lice (Figure 2). The drugs used for treatment or prophylaxis of canine ectoparasitic infestations are shown in Table 3. Each drug was considered as one response and multiple responses were accepted, resulting in 750 responses for recommended drugs. Isoxazolines were the most frequently recommended ectoparasiticide drug active (60.7\%), followed by fipronil (14.5\%).

Two hundred and five respondents suspected of poor efficacy. Fipronil inefficacy was suspected by 163 respondents (79.5\%) in the 19 Brazilian states with highest densities of dogs and highest numbers of respondents (Figure 1B). Suspicion of inefficacy of the recently launched isoxazoline compounds was reported by seven respondents (3.4\%) (Table 3).

Prophylaxis against ectoparasitic infestations was recommend by 333 (82.7\%) of the Brazilian veterinary practitioners. The regimes used by Brazilian veterinary practitioners for the prophylaxis of canine ectoparasites are shown in Table 4. A minimum of monthly systemic, topical and/or drug impregnated collar treatments was recommended by 87 respondents (21.5\%), followed by three-monthly treatments recommended by $83(20.6 \%)$. However, 93 respondents (23.0\%) recommended treatments at irregular times.

One hundred and eighty-eight respondents (46.6\%) frequently changed the drug products (but not necessarily the actives) used. Skin irritation caused by acaricide/insecticide impregnated collars was reported by 234 respondents (58\%). Three hundred and seventy-two of the veterinary practitioners (92.3\%) recommended environmental hygiene management alongside prophylactic or therapeutic drug use for canine ectoparasites. 


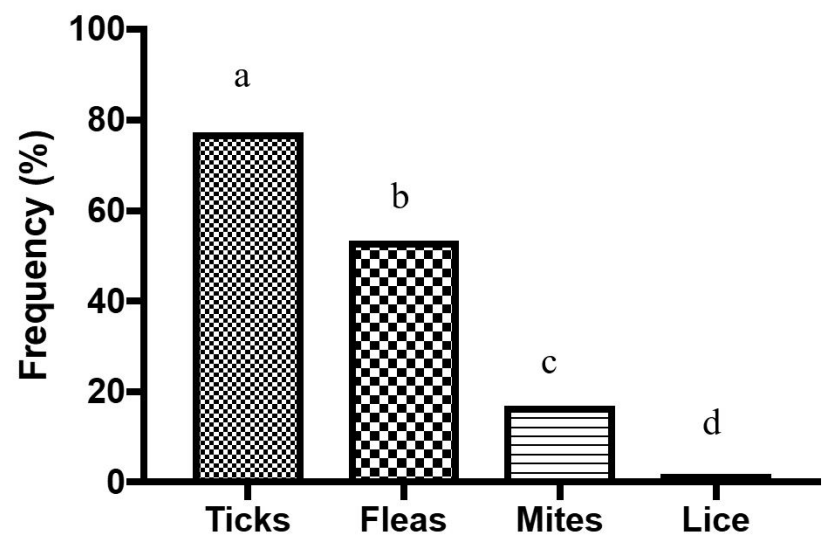

Figure 2. Frequency of the most common ectoparasites in dogs reported by veterinary practitioners from Brazil. Multiple responses were allowed. The different letters signify statistical differences with $\mathrm{p}<0.05$.

Table 3. The percentages and number of responses (in bracket) of the chemical group (in bold) and drug compounds recommended and suspect inefficacy used by Brazilian veterinarians to treat canine ectoparasites.

\begin{tabular}{|c|c|c|}
\hline Chemical group / compound & Recommended $^{1}$ & Suspect inefficacy ${ }^{2}$ \\
\hline Phenylpyrazol & $14.5(109)^{\mathrm{B}}$ & $79.5(163)^{A}$ \\
\hline Fipronil & $14.5(109)^{c}$ & $79.5(163)^{a}$ \\
\hline Isoxazolines & $60.7(455)^{A}$ & $3.4(7)^{c}$ \\
\hline Afoxolaner & $14.0(105)^{c}$ & $3.4(7)^{c}$ \\
\hline Fluralaner & $26.0(195)^{\mathrm{a}}$ & - \\
\hline Sarolaner & $20.7(155)^{\mathrm{b}}$ & - \\
\hline Pyrethroids & $4.3(32)^{\mathrm{D}}$ & $6.3(13)^{B, C}$ \\
\hline Deltamethrin & $2.8(21)^{f, g}$ & $2.9(6)^{c}$ \\
\hline Permethrin & $1.5(11)^{\mathrm{h}}$ & $3.4(7)^{c}$ \\
\hline Macrocyclic lactone & $6.1(46)^{D}$ & - \\
\hline Ivermectin & $1.3(10)^{\mathrm{h}}$ & - \\
\hline Selamectin & $4.8(36)^{e}$ & - \\
\hline Combinations & $5.5(41)^{\mathrm{D}}$ & - \\
\hline Imidacloprid, flumethrin & $3.6(27)^{e, f}$ & - \\
\hline Imidacloprid, methoprene & $1.9(14)^{\mathrm{g}, \mathrm{h}}$ & - \\
\hline Others & $8.9(67)^{d, c}$ & $10.7(22)^{b, B}$ \\
\hline
\end{tabular}

Multiple responses were allowed with $750{ }^{(1)}$ responses to recommend, and $205\left(^{(2)}\right.$ responses suspect of inefficacy. In bold the total number of responses by chemical group or combination. The different letters signify statistical differences with $p<0.05$, being lower letters among the compounds and capital letters among the chemical group or combination.

Table 4. The percentages and number $(\mathrm{n})$ of responses (in bracket) of regimes used by Brazilian veterinarians for prophylaxis of canine ectoparasites.

\begin{tabular}{ll}
\hline \multicolumn{1}{c}{ Regimes } & \% (n) \\
\hline Prophylaxis of ectoparasites & \\
Every month & $21.5(87)^{\mathrm{a}, \mathrm{b}}$ \\
Every 3-months & $20.6(83)^{\mathrm{a}, \mathrm{b}}$ \\
Every 6-months & $17.3(70)^{\mathrm{b}}$ \\
Other (irregular intervals) & $23.0(93)^{\mathrm{a}}$ \\
Not answer & $17.3(70)^{\mathrm{b}}$ \\
\hline
\end{tabular}

The different letters signify statistical differences with $p<0.05$. 


\section{Discussion}

The climatic conditions in tropical areas are favourable to the development of environmental parasite stages, resulting in high levels of infectious challenge (Robinson et al., 1989; Epe, 2009). In Brazil, dogs from different regions are hosts for a large number of pathogenic flea, louse, mite, tick and fly ectoparasites, and tapeworm and roundworm gastrointestinal endoparasites (Dantas-Torres \& Otranto, 2014). Effective control regimes specific to Brazilian dogs are essential to ensure satisfactory states of animal welfare (Despommier, 2003; Epe, 2009). The value of antiparasitic drugs is threatened by the emergence of resistance or tolerance; hence recommendations must account for responsible and potentially sustainable therapeutic and prophylactic drug use. In this report, we describe the first wide-scale survey of Brazilian veterinary practitioners' practices and attitudes towards canine parasite management.

Dog owners have an important role to play, as they are responsible for putting recommendations into practice. According to $71.4 \%$ of the veterinarians surveyed, dog owners are concerned about the impact of highly visible ectoparasites (Costa-Junior et al., 2012; Heukelbach et al., 2012) and gastrointestinal helminths on their animals. Similarly, half of the pet owners from a study in Canadá had concern for their pet's parasites, and the veterinarians are the primary sources of owner education (Evason et al., 2021).

Veterinary practitioners have an important role to play in educating pet owners with different financial and educational backgrounds (Pereira et al., 2016) about parasites, which present animal welfare and public health risks (Strube et al., 2019). However, it is imperative to add owner's education in a routine of veterinary practice to reduce the risk of pet parasitism and zoonoses (Palmer et al., 2010; Baneth et al., 2012). On the other hand, veterinarian's education and scientific updating are also necessary to improve the knowledge and consequently the control of pet parasitism and zoonoses (Overgaauw \& Boersema, 1996).

It has been recommended that all dogs should be tested for gastrointestinal parasites at least once every three months and after administration of anthelmintic drugs (TroCCAP, 2019), to account for continuous reinfection (Little et al., 2009) as prevails in Brazil. Despite this recommendation, 52.6\%, of the Brazilian veterinary practitioners did not request coproparasitological examination and the majority simply recommended fixed interval treatments. In other countries, the proportion of veterinary practitioners that recommend the treatment without a coprological diagnostic increased in the last years (Kornblatt \& Schantz, 1980; Harvey et al., 1991; Stull et al., 2007). The coprological diagnosis of gastrointestinal parasites of dogs in Brazil is predominantly based on relatively inexpensive sedimentation or floatation methods. Better understanding is needed concerning why these are not widely adopted, for example due to potential inaccessibility or perceptions of poor sensitivity.

Prophylaxis for gastrointestinal helminths was performed every 3 -months by $46 \%$ of the veterinary practitioners and $61 \%$ recommended repeat treatments after 15 days (Table 4). This repetition is necessary because most of the products recommended have reduced action against immature or migratory stages, for example pyrantel only targets intestine stages while benzimidazoles have short half-lives (Plumb, 2018). The high rate of non-targeted drug administration by Brazilian veterinary practitioners, could potentially result in a high selection pressure for anthelmintic resistance (Shalaby, 2013), especially in tropical and subtropical regions that have a favorable conditions for the development of gastrointestinal parasites (Klimpel et al., 2010; Dantas-Torres \& Otranto, 2014; Alho et al., 2018). Dogs owners from Belgium, Netherlands, and Finland had lower anthelmintic treatment frequency than in the present study (Pullola et al., 2006; Lempereur et al., 2020), which can be justified by epidemiology and risk factors of the nematodes in these temperate countries. Nevertheless, the number of dogs deworm in the UK is similar to Brazil, demonstrating that there is also an owner behavioral aspect (Pennelegion et al., 2020).

Regional specific knowledge of the epidemiology of parasites is necessary to inform appropriate drug treatment, reducing the selection pressure for resistance. Simply increasing the frequency of treatment incurs increased costs and potentially increases the selection pressure for resistance. Resistant strains of Ancylostoma caninum and Dipylidium caninum have been reported in the USA (Jesudoss Chelladurai et al., 2018; Jimenez-Castro et al., 2019; Kitchen et al., 2019). A mutation in a $\beta$-tubulin gene has been reported linked benzimidazole resistance in $A$. caninum from Brazil (Furtado et al., 2014). It is, therefore, necessary to monitor to the effectiveness of anthelmintic drugs used in the management of canine gastrointestinal helminths in order to respond to emergence of resistance (Kopp et al., 2007).

Anthelmintic drug treatments of puppies for the control of maternally transmitted nematodes should start at the age of two weeks old, and be repeated every 15 days until the age of eight weeks (TroCCAP, 2019). Thereafter, treatments should be monthly in areas with high prevalence of gastrointestinal helminths (TroCCAP, 2019). For these strategies, $62.2 \%$ of the participating veterinary practitioners recommended the use of anthelmintic drug combination products, in particular involving praziquantel plus pyrantel plus a benzimidazole drug (Table 1), which is similar to that used in veterinary practice in other countries (Matos et al., 2015). Combinations of broad spectrum anthelmintics are required to treat the polyparasitism that it commonly encountered in Brazilian kennel 
dogs. This strategy is also potentially helpful in achieving improved, additive efficacy, decreased toxicity, and reduced development of drug resistance (Bartram et al., 2012; Rinaldi et al., 2015; Lanusse et al., 2018).

According to the veterinary practitioners' perspective, ticks, followed by fleas, mites and lice are the most important ectoparasites of dogs in Brazil (Figure 2). In the same way, Rhipicephalus sanguineus sensu lato, Ctenocephalides canis and Ctenocephalides felis felis are considered the most common canine ectoparasites worldwide, albeit the prevalence and importance of infestation differ according to the geographic region of dogs (Costa-Junior et al., 2012; Ebrahimzade et al., 2016).

Regular use of ectoparasiticides is widely recommended to protect dogs against ectoparasites and the pathogens that they transmit (CAPC, 2019). 82.7\% of the respondents recommend the use of ectoparasiticide products (impregnated collars, pour-ons, spot-ons or tablets) as a prophylactic measure, with $21.5 \%$ recommending administration every month and $20.6 \%$ recommending three-monthly treatments.

Brazil is an endemic area for canine visceral leishmaniasis and dogs serve as a source of infection for phlebotomine sand flies (Rocha et al., 2020). The use of insecticide impregnated dog collars, which have both an anti-feeding and insecticidal activity is considered to be a useful tool for canine control of leishmaniasis (David et al., 2001). In addition to being used as an insecticide against sand flies, these collars are also recommended for tick and flea control (Silva et al., 2018). The dog collars constantly release the active chemical; and long half-life residues may be responsible for the selection of resistance in ticks (Beirão et al., 2009). 58\% of the veterinary practitioner respondents had noticed skin irritation in dogs as a side-effect to collars.

The present study addresses the frequency of application or administration of acaricides in dogs in Brazil. The most frequently recommended drugs for the control of ectoparasites were fluralaner (26\%), sarolaner (20.7\%), afoxolaner (14\%), and fipronil (14.5\%). Slightly more than half of respondents recommend the rotation of these principles. Interestingly, all of the drugs mentioned in the control of ectoparasites, with the exception of fipronil, are the latest to be released on the market. Frequent use of ectoparasiticides may exert a selection pressure for resistance or tolerance in tick populations (Rodriguez-Vivas et al., 2017; Becker et al., 2019).

Several studies have shown resistance of $R$. sanguineus s.l. to permethrin in the USA (Eiden et al., 2016), cypermethrin and coumaphos in Brazil (Borges et al., 2007), amitraz in Panama (Miller et al., 2001), and ivermectin in Mexico (Rodriguez-Vivas et al., 2017). In Brazil, the first report of $R$. sanguineus s.l. resistance to fipronil was recently published (Becker et al., 2019), supporting the veterinary practitioners' perceptions of inefficacy of in this study (Table 3). The suspicion of inefficacy of recently introduced isoxazolines is noteworthy.

Almost all of the veterinary practitioner respondents recommend environmental management for the control of ectoparasites in dogs in Brazil. The knowledge that ticks and fleas are non-permanent parasites makes it necessary to consider the management of environmental stages (Dantas-Torres \& Otranto, 2014). Despite the variety of available products with proven efficacy against canine ectoparasites, there are no guidelines for the control of ectoparasites in the environment that take into account the different regions of Brazil. It is necessary to remind veterinary practitioners that the chemical control of other arthropods that co-infect dogs is more complex, and that the misuse of these compounds can cause environmental pollution and toxicity to humans and other organisms (Dantas-Torres \& Otranto, 2014; Paz et al., 2008).

This study shows the wide use of antiparasitic products and treatment regimens for parasite control in dogs in Brazil. The isoxazoline and combination of anthelmintic compounds are the most common drugs to prevent or treat ectoparasites and gastrointestinal nematodes, respectively. The suspect of the inefficacy of antiparasitic drugs is shared among the veterinary practitioners from Brazil. It is necessary to improve awareness of the use of antiparasitic products that require the attention of veterinary practitioners and industry to applied effective and sustainable parasite control strategies.

\section{Acknowledgements}

The authors acknowledge the financial support received from CNPq (Brazilian National Council for Scientific and Technological Development), FAPEMA (Maranhão State Research Foundation) and FINEP (Funding Authority for Studies and Projects) (PRONEM 01773/14 and IECT (Science and Technology Institute of Maranhão) Biotechnology). This study was financed in part by CAPES, Finance Code 001. The authors wish to tanks CNPq to awarding a fellowship to L.M. Costa-Júnior and scholarship to M.N.G and thank FAPEMA and CAPES (Brazilian Federal Agency for support and evaluation of graduate education) for the scholarships to T.L.V, I.C.S, C.P.T, and N.C.S. We also thank COMAC from SINDAN for market data support and Vicente F. Pinheiro-Neto for the questionnaire collection. 


\section{References}

Alho AM, Lima C, Colella V, Madeira de Carvalho L, Otranto D, Cardoso L. Awareness of zoonotic diseases and parasite control practices : a survey of dog and cat owners in Qatar. Parasit Vectors 2018; 11(1): 133. http://dx.doi.org/10.1186/s13071-018-27200. PMid:29554937.

Associação Brasileira da Indútria de Produtos de Origem Animal - ABINPET. Mercado Pet Brasileiro [online]. 2019 [cited 2020 Mar 5]. Available from: http://abinpet.org.br

Baneth G, Bourdeau P, Bourdoiseau G, Bowman D, Breitschwerdt E, Capelli G, et al. Vector-borne diseases--constant challenge for practicing veterinarians: recommendations from the CVBD World Forum. Parasit Vectors 2012; 5(1): 55. http://dx.doi. org/10.1186/1756-3305-5-55. PMid:22433172.

Bartram DJ, Leathwick DM, Taylor MA, Geurden T, Maeder SJ. The role of combination anthelmintic formulations in the sustainable control of sheep nematodes. Vet Parasito/ 2012; 186(3-4): 151-158. http://dx.doi.org/10.1016/j.vetpar.2011.11.030. PMid:22245073.

Becker S, Webster A, Doyle RL, Martins JR, ReckJ, Klafke GM. Resistance to deltamethrin, fipronil and ivermectin in the brown dog tick, Rhipicephalus sanguineus sensu stricto, Latreille (Acari: ixodidae). Ticks Tick Borne Dis 2019; 10(5): 1046-1050. http://dx.doi. org/10.1016/j.ttbdis.2019.05.015. PMid:31175029.

Beirão BCB, Rosinelli ADS, Da Silva LCS, Santos GDGC, Ruthes LD, Molento MB. Protocolos utilizados em consultórios, clínicas e hospitais veterinários para o controle de endo e ectoparasitas em pequenos animais em Curitiba. Arch Vet Sci 2009; 14(4): 221-227. http://dx.doi.org/10.5380/avs.v14i4.13435.

Borges LMF, Soares SF, Fonseca IN, Chaves VV, Louly CCB. Resistência acaricida em larvas de Rhipicephalus sanguineus (Acari: Ixodidae) de Goiânia-GO, Brasil. Rev Patol Trop 2007; 36(1): 87-95.

Chomel BB, Sun B. Zoonoses in the Bedroom. Emerg Infect Dis 2011; 17(2): 167-172. http://dx.doi.org/10.3201/eid1702.101070. PMid:21291584.

Companion Animal Parasite Council - CAPC. [online]. 2019 [cited 2019 Nov 25]. Available from: https://capcvet.org/guidelines/ hookworms/

Conselho Federal de Medicina Veterinária - CFMV. [online]. 2019 [cited 2020 Aug 25]. Available from: http://portal.cfmv.gov.br/ noticia/index/id/5827/secao/6

Costa-Junior LM, Rembeck K, Mendonça FLM, Azevedo SC, Passos LMF, Ribeiro MFB. Occurrence of ectoparasites on dogs in rural regions of the state of Minas Gerais, Brazil. Rev Bras Parasito/ Vet 2012; 21(3): 237-242. http://dx.doi.org/10.1590/S198429612012000300011. PMid:23070433.

Dantas-Torres F, Ketzis J, Mihalca AD, Baneth G, Otranto D, Tort GP, et al. TroCCAP recommendations for the diagnosis, prevention and treatment of parasitic infections in dogs and cats in the tropics. Vet Parasito/ 2020; 283: 109167. http://dx.doi.org/10.1016/j. vetpar.2020.109167. PMid:32580071.

Dantas-Torres F, Otranto D. Dogs, cats, parasites, and humans in Brazil: opening the black box. Parasit Vectors $2014 ; 7(1): 22$. http://dx.doi.org/10.1186/1756-3305-7-22. PMid:24423244.

David JR, Stamm LM, Bezerra HS, Souza RN, Killick-Kendrick R, Lima JWO. Deltamethrin-impregnated dog collars have a potent anti-feeding and insecticidal effect on Lutzomyia longipalpis and Lutzomyia migonei. Mem Inst Oswaldo Cruz 2001; 96(6): 839-847. http://dx.doi.org/10.1590/S0074-02762001000600018. PMid:11562713.

Despommier D. Toxocariasis: clinical aspects, epidemiology, medical ecology, and molecular aspects. Clin Microbiol Rev 2003; 16(2): 265-272. http://dx.doi.org/10.1128/CMR.16.2.265-272.2003. PMid:12692098.

Ebrahimzade E, Fattahi R, Ahoo MB. Ectoparasites of stray dogs in Mazandaran, Gilan and Qazvin Provinces, north and center of Iran. J Arthropod Borne Dis 2016; 10(3): 364-369. PMid:27308294.

Eiden AL, Kaufman PE, Allan SA, Oi F. Establishing the discriminating concentration for permethrin and fipronil resistance in Rhipicephalus sanguineus (Latreille) (Acari : Ixodidae), the brown dog tick. Pest Manag Sci 2016; 72(7): 1390-1395. http://dx.doi. org/10.1002/ps.4165. PMid:26449370.

Epe C. Intestinal Nematodes: biology and control. Vet Clin North Am Small Anim Pract 2009; 39(6): 1091-1107, vi-vii. http://dx.doi. org/10.1016/j.cvsm.2009.07.002. PMid:19932365.

European Scientific Counsel Companion Animal Parasites - ESCCAP. [online]. 2019 [cited 2019 Nov 3]. Available from: https:// www.esccap.org/

Evason M, McGrath M, Stull J. Companion animal preventive care at a veterinary teaching hospital - Knowledge, attitudes, and practices of clients. Can Vet J 2021; 62(5): 484-490. PMid:33967287.

Furtado LFV, Bello ACPP, dos Santos HA, Carvalho MRS, Rabelo ÉML. First identification of the F200Y SNP in the $\beta$-tubulin gene linked to benzimidazole resistance in Ancylostoma caninum. Vet Parasitol 2014; 206(3-4): 313-316. https://doi.org/10.1016/j.vetpar.2014.10.021. 
Harvey JB, Roberts JM, Schantz PM. Survey of veterinarians' recom mendations for treatment and control of intestinal parasites in dogs: public health implications. J Am Vet Med Assoc 1991; 199(6): 702-707. PMid:1955360.

Heukelbach J, Frank R, Ariza L, de Sousa Lopes I, de Assis E Silva A, Borges AC, et al. High prevalence of intestinal infections and ectoparasites in dogs, Minas Gerais State (Southeast Brazil). Parasitol Res 2012; 111(5): 1913-1921. http://dx.doi.org/10.1007/ s00436-012-3037-0. PMid:22825284.

Instituto Brasileiro de Geografia e Estatística - IBGE. Censo Brasileiro de 2010. Rio de Janeiro: IBGE; 2012.

Instituto Brasileiro de Geografia e Estatística - IBGE. Biomas e sistema costeiro-marinho do Brasil: compatível com a escala 1:250 000. Rio de Janeiro: IBGE; 2019.

Jesudoss Chelladurai J, Kifleyohannes T, Scott J, Brewer MT. Praziquantel Resistance in the Zoonotic Cestode Dipylidium caninum. Am J Trop Med Hyg 2018; 99(5): 1201-1205. http://dx.doi.org/10.4269/ajtmh.18-0533. PMid:30226153.

Jimenez Castro PD, Howell SB, Schaefer JJ, Avramenko RW, Gilleard JS, Kaplan RM. Multiple drug resistance in the canine hookworm Ancylostoma caninum: an emerging threat? Parasit Vectors 2019; 12(1): 576. http://dx.doi.org/10.1186/s13071-0193828-6. PMid:31818311.

Kitchen S, Ratnappan R, Han S, Leasure C, Grill E, Iqbal Z, et al. Isolation and characterization of a naturally occurring multidrugresistant strain of the canine hookworm, Ancylostoma caninum. Int J Parasitol 2019; 49(5): 397-406. http://dx.doi.org/10.1016/j. ijpara.2018.12.004. PMid:30771359.

Klimpel S, Heukelbach J, Pothmann D, Rückert S. Gastrointestinal and ectoparasites from urban stray dogs in Fortaleza (Brazil): high infection risk for humans? Parasitol Res 2010; 107(3): 713-719. http://dx.doi.org/10.1007/s00436-010-1926-7. PMid:20532563.

Kopp SR, Kotze AC, McCarthy JS, Coleman GT. High-level pyrantel resistance in the hookworm Ancylostoma caninum. Vet Parasitol 2007; 143(3-4): 299-304. http://dx.doi.org/10.1016/j.vetpar.2006.08.036. PMid:17011128.

Kornblatt AN, Schantz PM. Veterinary and public health considerations in canine roundworm control: a survey of practicing veterinarians. J Am Vet Med Assoc 1980; 177(12): 1212-1215. PMid:7440322.

Lanusse C, Canton C, Virkel G, Alvarez L, Costa-Junior L, Lifschitz A. Strategies to optimize the efficacy of anthelmintic drugs in ruminants. Trends Parasitol 2018; 34(8): 664-682. http://dx.doi.org/10.1016/j.pt.2018.05.005. PMid:29960843.

Lempereur L, Nijsse R, Losson B, Marechal F, De Volder A, Schoormans A, et al. Coprological survey of endoparasite infections in owned dogs and owners' perceptions of endoparasite control in Belgium and the Netherlands. Vet Parasitol Reg Stud Reports 2020; 22: 100450. http://dx.doi.org/10.1016/j.vprsr.2020.100450. PMid:33308762.

Little SE, Johnson EM, Lewis D, Jaklitsch RP, Payton ME, Blagburn BL, et al. Prevalence of intestinal parasites in pet dogs in the United States. Vet Parasitol 2009; 166(1-2): 144-152. http://dx.doi.org/10.1016/j.vetpar.2009.07.044. PMid:19716659.

Matos M, Alho AM, Owen SP, Nunes T, Madeira de Carvalho L. Parasite control practices and public perception of parasitic diseases: A survey of dog and cat owners. Prev Vet Med 2015; 122(1-2): 174-180. http://dx.doi.org/10.1016/j.prevetmed.2015.09.006. PMid:26404913.

Miller RJ, George JE, Guerrero F, Carpenter L, Welch JB. Characterization of Acaricide Resistance in Rhipicephalus sanguineus (Latreille) (Acari: Ixodidae) Collected from the Corozal Army Veterinary Quarantine Center, Panama. J Med Entomol 2001; 38(2): 298-302. http://dx.doi.org/10.1603/0022-2585-38.2.298. PMid:11296838.

Miot HA. Sample size in clinical and experimental trials. J Vasc Bras 2011; 10(4): 275-279. http://dx.doi.org/10.1590/S167754492011000400001. PMid:30787944.

Overgaauw PA, Boersema JH. Assessment of an educational campaign by practicing veterinarians in The Netherlands on human and animal Toxocara infections. Tijdschr Diergeneeskd 1996; 121(21): 615-618. PMid:8966710.

Palmer CS, Robertson ID, Traub RJ, Rees R, Andrew Thompson RC. Intestinal parasites of dogs and cats in Australia: the veterinarian's perspective and pet owner awareness. Vet J 2010; 183(3): 358-361. http://dx.doi.org/10.1016/j.tvjl.2008.12.007.

Paz GF, Leite RC, de Oliveira PR. Controle de Rhipicephalus sanguineus (Latreille, 1806) (Acari: Ixodidae) no canil da Escola de Veterinária da UFMG, Belo Horizonte, Minas Gerais, Brasil. Rev Bras Parasitol Vet 2008; 17(1): 41-44. http://dx.doi.org/10.1590/ S1984-29612008000100009. PMid:18554440.

Pennelegion C, Drake J, Wiseman S, Wright I. Survey of UK pet owners quantifying internal parasite infection risk and deworming recommendation implications. Parasit Vectors 2020; 13(1): 218. http://dx.doi.org/10.1186/s13071-020-04086-2. PMid:32336273.

Pereira A, Martins Â, Brancal H, Vilhena H, Silva P, Pimenta P, et al. Parasitic zoonoses associated with dogs and cats: A survey of Portuguese pet owners' awareness and deworming practices. Parasit Vectors 2016; 9(1): 245. http://dx.doi.org/10.1186/s13071016-1533-2. PMid:27160667.

Plumb DC. Plumb's Veterinary Drug Handbook: Desk. 9th ed. Hoboken, NJ, USA: John Wiley \& Sons; 2018. 
Pullola T, Vierimaa J, Saari S, Virtala AM, Nikander S, Sukura A. Canine intestinal helminths in Finland: prevalence, risk factors and endoparasite control practices. Vet Parasitol 2006; 140(3-4): 321-326. http://dx.doi.org/10.1016/j.vetpar.2006.04.009. PMid:16650936.

Rinaldi L, Pennacchio S, Musella V, Maurelli MP, La Torre F, Cringoli G. Helminth control in kennels: is the combination of milbemycin oxime and praziquantel a right choice? Parasit Vectors 2015; 8(1): 30. http://dx.doi.org/10.1186/s13071-015-0647-2. PMid:25595418.

Robinson RD, Thompson DL, Lindo JF. A survey of intestinal helminths of well-cared-for dogs in Jamaica, and their potential public health significance. J Helminthol 1989; 63(1): 32-38. http://dx.doi.org/10.1017/S0022149X00008695. PMid:2723384.

Rocha MF, Michalsky ÉM, de Oliveira Lara-Silva F, Valadão JL, França-Silva JC, Pinheiro LC, et al. Dogs with divergent serology for visceral leishmaniasis as sources of Leishmania infection for Lutzomyia longipalpis phlebotomine sand flies - an observational study in an endemic area in Brazil. PLoS Neg/ Trop Dis 2020; 14(2): e0008079. http://dx.doi.org/10.1371/journal.pntd.0008079. PMid:32078634.

Rodriguez-Vivas RI, Ojeda-Chi MM, Trinidad-Martinez I, Pérez de León AA. First documentation of ivermectin resistance in Rhipicephalus sanguineus sensu lato (Acari: ixodidae). Vet Parasito/ 2017; 233: 9-13. http://dx.doi.org/10.1016/j.vetpar.2016.11.015. PMid:28043394.

Shalaby HA. Anthelmintics resistance; how to overcome it? Iran J Parasitol 2013; 8(1): 18-32. PMid:23682256.

Silva RAE, Andrade AJ, Quint BB, Raffoul GES, Werneck GL, Rangel EF, et al. Effectiveness of dog collars impregnated with 4\% deltamethrin in controlling visceral leishmaniasis in Lutzomyia longipalpis (Diptera: Psychodidade: Phlebotominae) populations. Mem Inst Oswaldo Cruz 2018; 113(5): e170377. http://dx.doi.org/10.1590/0074-02760170377. PMid:29590235.

Sindicato Nacional da Indústria de Produtos para Saúde Animal - SINDAN. Compêndio de produtos veterinários [online]. 2019 [cited 2019 Nov 25]. Available from: https://sistemas.sindan.org.br/cpvs/pesquisar.aspx

Strube C, Neubert A, Springer A, Von Samson-Himmelstjerna G. Survey of German pet owners quantifying endoparasitic infection risk and implications for deworming recommendations. Parasit Vectors 2019; 12(1): 203. http://dx.doi.org/10.1186/s13071-0193410-2. PMid:31053079.

Stull JW, Carr AP, Chomel BB, Berghaus RD, Hird DW. Small animal deworming protocols, client education, and veterinarian perception of zoonotic parasites in western Canada. Can Vet J 2007; 48(3): 269-276. http://dx.doi.org/10.4141/cjas68-037. PMid:17436903.

Traub RJ, Irwin P, Dantas-Torres F, Tort GP, Labarthe NV, Inpankaew T, et al. Toward the formation of a Companion Animal Parasite Council for the Tropics (CAPCT). Parasit Vectors 2015; 8(1): 271. http://dx.doi.org/10.1186/s13071-015-0884-4. PMid:25963851.

Tropical Council for Companion Animal Parasites - TroCCAP. Guidelines for the diagnosis, treatment and control of canine endoparasites in the tropics [online]. 2019 [cited 2020 Aug 21]. Available from: https://www.troccap.com/2017press/wp-content/ uploads/2019/05/TroCCAP_Canine_Endo_Guidelines_English_Ver2.pdf 